\title{
Clinical significance of secreted protein, acidic and cysteine-rich gene expression in patients with stage II/III gastric cancer following curative resection and adjuvant chemotherapy with $S-1$
}

\author{
YOSHIHIRO SUZUKI ${ }^{1}$, TAKASHI OSHIMA ${ }^{1}$, KAZUE YOSHIHARA ${ }^{1}$, KENTARO SAKAMAKI $^{2}$, \\ TORU AOYAMA ${ }^{1}$, HARUHIKO $\mathrm{CHO}^{1}$, MANABU SHIOZAWA ${ }^{1}$, TAKAKI YOSHIKAWA ${ }^{1}$, \\ YASUSHI RINO $^{1}$, TOSHIO IMADA ${ }^{3}$ and MUNETAKA MASUDA ${ }^{1}$
}

\begin{abstract}
Departments of ${ }^{1}$ Surgery and ${ }^{2}$ Biostatistics and Epidemiology, Yokohama City University, Yokohama, Kanagawa 236-0004;
${ }^{3}$ Department of Surgery, Yokohama City Nanbu Hospital, Yokohama, Kanagawa 234-0054, Japan
\end{abstract}

Received July 26, 2016; Accepted December 20, 2017

DOI: $10.3892 / \mathrm{ol} .2018 .8248$

\begin{abstract}
The standard treatment for stage II/III gastric cancer is surgical resection followed by adjuvant chemotherapy with fluoropyrimidine anticancer agents, including $\mathrm{S}-1$. The protein, secreted protein, acidic and cysteine-rich $(S P A R C)$, promotes angiogenesis, and the proliferation and migration of cancer cells. The present study evaluated the significance of expression of the SPARC gene in patients with stage II/III gastric cancer who had undergone surgical resection and adjuvant chemotherapy with $\mathrm{S}-1$. In the present study, reverse transcription-quantitative polymerase chain reaction was performed in order to quantify mRNA expression levels of SPARC in cancer tissues and adjacent normal mucosa obtained from 134 patients with stage II/III gastric cancer who had undergone surgical resection followed by adjuvant chemotherapy with $\mathrm{S}-1$. The mRNA expression level of SPARC was significantly higher in cancer tissues than in adjacent normal mucosa $(\mathrm{P}=0.0012)$. Additionally, the 5-year overall survival rate was significantly poorer in patients with high $S P A R C$ gene expression than in those with low expression $(\mathrm{P}<0.0001)$. Furthermore, multivariate analysis indicated that high SPARC mRNA expression was a significant predictor of poorer survival in patients with stage II/III gastric cancer who had undergone surgical resection and adjuvant chemotherapy with S-1 (HR, 5.347; $\mathrm{P}<0.0001)$. Therefore, high expression of the SPARC gene may be a useful predictor of outcomes in patients with stage II/III gastric cancer, who have received treatment involving surgical resection and adjuvant chemotherapy with S-1.
\end{abstract}

Correspondence to: Dr Takashi Oshima, Department of Surgery, Yokohama City University, 3-9 Fukuura, Yokohama, Kanagawa 236-0004, Japan

E-mail: ohshimatakashi@yahoo.co.jp

Key words: secreted protein acidic and rich in cysteine, gastric cancer, biomarker

\section{Introduction}

Gastric cancer is the third leading cause of cancer-associated mortality worldwide, accounting for 723,000 mortalities in 2012 (1). Advanced gastric cancer continues to result in a high mortality rate despite progress in surgical techniques, diagnostic procedures and chemotherapy. The standard therapy for stage II/III gastric cancer is surgical resection followed by adjuvant chemotherapy (2). Gastrectomy with D2-lymph-node dissection, followed by chemotherapy with S-1 for 1 year, was demonstrated to significantly improve survival in the Adjuvant Chemotherapy Trial of S-1 for Gastric Cancer $(2,3)$. However, cancer recurs in a large number of patients even in those who have received therapy. Therefore, novel diagnostic and treatments approaches, including those based on personalized medicine and individual biomarker analysis, are required.

Secreted protein acidic and rich in cysteine (SPARC), also known as osteonectin, is a bone-specific protein that binds selectively to both hydroxyapatite and collagen (4). Basement membrane protein 40 , obtained from the basement membrane of a tumor, is also identical to SPARC (5). SPARC is expressed by a number of cell types, and its expression contributes to the production and activity of matrix metalloproteinases, which are important for embryogenesis, adult bone organization, wound healing and tissue remodeling (6,7). SPARC also regulates other biological functions, including cell proliferation, migration, de-adhesion, differentiation and angiogenesis (8). $S P A R C$ expression is upregulated in many types of cancer (9), including pancreatic cancer, breast cancer, prostate cancer, colorectal cancer, gastric cancer and gliomas (7,10-15). SPARC expression is also associated with patient outcomes and clinicopathological features, including the depth of cancer cell invasion and metastasis $(16,17)$.

The present study measured mRNA expression levels of SPARC in gastric cancer tissues and adjacent normal mucosa obtained from 134 patients with stage II/III gastric cancer. The objective of the present study was to evaluate the clinical significance of SPARC gene expression in patients with stage II/III gastric cancer after curative resection and adjuvant chemotherapy with S-1. 


\section{Materials and methods}

Patients and tissue samples. A total of 2,900 patients with histologically confirmed gastric adenocarcinoma underwent gastrectomy between June 2002 and May 2010 at the following institutions: The Department of Surgery at Yokohama City University (Yokohama, Japan), the Gastroenterological Center at Yokohama City Medical Center (Yokohama, Japan) and the Department of Gastrointestinal Surgery at Kanagawa Cancer Center (Yokohama, Japan). Among these 2,900 patients, 399 agreed to participate in the present study by donating samples of gastric tissue. Among these 399 patients, 237 were diagnosed with stage II/III cancer and underwent surgical resection as part of their primary treatment. Tissue specimens of cancer tissue and adjacent normal mucosa were obtained during curative resection from 134 patients with stage II/III gastric cancer who had received adjuvant chemotherapy with S-1 between June 2002 and May 2010. The patient's age ranged from 42-82 years old (average, 65.3 years old), and the sex is 42 males and 92 females. Eligible criteria include PS 0-1 cases and cases where functions of major organs are preserved. As a reference group, the remaining 103 patients diagnosed with stage II/III gastric cancer, who had undergone surgical resection but had not received adjuvant S-1 chemotherapy, were also included in the present study (Fig. 1). All tissue samples were embedded in Optimal Cutting Temperature compound (Sakura Finetek USA, Inc., Torrance, CA, USA) and immediately stored at $-80^{\circ} \mathrm{C}$ until further use. Tissue specimens were stained with hematoxylin and eosin and were examined histologically. Sections that consisted of $>80 \%$ cancer cells were subsequently used to prepare total RNA. Tumors were staged according to the seventh edition of the Union for International Cancer Control Tumor-Node-Metastasis (TNM) classification of malignant tumors (18) (Fig. 2). Written informed consent was obtained from each patient, and study protocols were approved by the Ethics Committees of Yokohama City University Medical Center, Yokohama City University (approval number: 18-7A-4) and Kanagawa Cancer Center (approval number: epidemiological study-29) prior to the initiation of the present study. No other malignancies were identified in patients enrolled in the present study.

Cell lines. Human gastric cancer cell lines (MKN1, MKN7, MKN45, MKN74, NUGC-3, NUGC-4 and KATO III) were provided by the Japanese Cancer Research Bank (Tokyo, Japan). Cell lines were maintained in RPMI-1640 medium (Invitrogen; Thermo Fisher Scientific, Inc., Waltham, MA, USA), supplemented with $10 \%$ fetal bovine serum (Equitech-Bio, Inc., Kerrville, TX, USA), and $100 \mathrm{U} / \mathrm{ml}$ penicillin G and streptomycin (Invitrogen; Thermo Fisher Scientific, Inc.). Cells were incubated in $5 \% \mathrm{CO}_{2}$ at $37^{\circ} \mathrm{C}$ and passaged every 3-4 days, except for the MKN7 cells, which were passaged every 7 days because the passage time was different from other cell lines.

RNA extraction and cDNA synthesis. Total RNA was extracted from gastric cancer tissues and adjacent normal mucosa using TRIzol reagent (Gibco; Thermo Fisher Scientific, Inc.). cDNA was synthesized from $2 \mu \mathrm{g}$ total RNA using an iScript cDNA Synthesis kit (Bio-Rad Laboratories, Inc., Hercules, CA, USA), prior to being diluted with water to $2 \mu \mathrm{g} / \mu \mathrm{l}$ and stored at $-20^{\circ} \mathrm{C}$ until use.

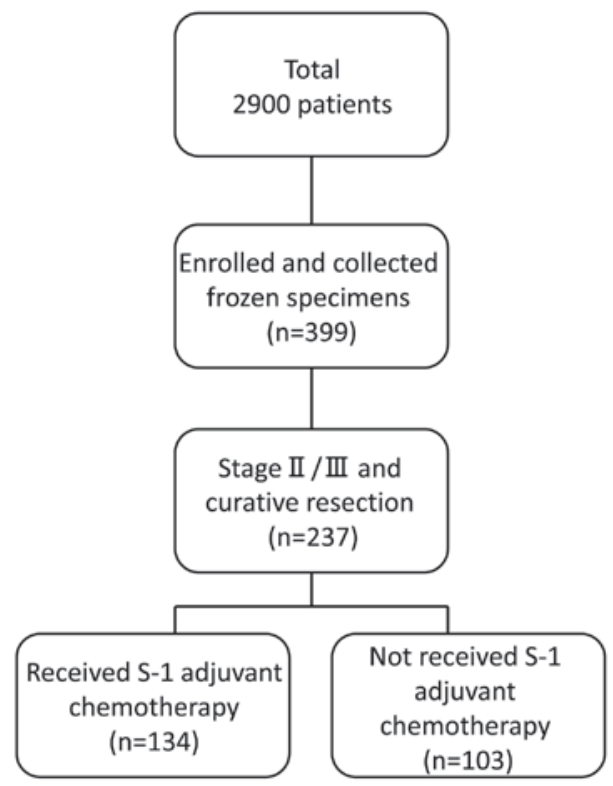

Figure 1. Flow diagram of the patients enrolled in the present study.

\begin{tabular}{|c|c|c|c|c|c|}
\hline & NO & N1 & N2 & N3 & M1 \\
\hline T1a (M), T1b (SM) & IA & IB & $\mathbb{I A}$ & $\mathbb{B} B$ & \\
\hline T2 (MP) & $\mathbb{I} B$ & $\mathbb{I A}$ & $\mathbb{B} B$ & $\mathbb{I A}$ & \\
\hline T3 (SS) & $\mathbb{I A}$ & $\mathbb{I B}$ & $\mathbb{I A}$ & $\mathbb{I B}$ & $\mathbb{N}$ \\
\hline T4a (SE) & $\mathbb{I B}$ & $\mathbb{I A}$ & $\mathbb{1 B}$ & $\mathbb{I C}$ & \\
\hline T4b (SI) & $\mathbb{I B}$ & $\mathbb{I B}$ & $\mathbb{I C}$ & $\mathbb{I C}$ & \\
\hline
\end{tabular}

Figure 2. Tumor-Node-Metastasis (TNM) classification.

Reverse-transcription polymerase chain reaction (RT-PCR). RT-PCR was performed using SPARC gene-specific oligonucleotide primers (Table I). SPARC was amplified using the following thermocycling conditions: 40 cycles of denaturation at $95^{\circ} \mathrm{C}$ for $1 \mathrm{~min}$, annealing at $55^{\circ} \mathrm{C}$ for $1 \mathrm{~min}$ and primer extension at $72^{\circ} \mathrm{C}$ for $1 \mathrm{~min}$. $\beta$-actin was used as an internal loading control. $\beta$-actin was amplified using the following thermocycling conditions: 40 cycles of denaturation at $95^{\circ} \mathrm{C}$ for $1 \mathrm{~min}$, annealing at $60^{\circ} \mathrm{C}$ for $1 \mathrm{~min}$ and primer extension at $72^{\circ} \mathrm{C}$ for $1 \mathrm{~min}$. PCR products were separated by gel electrophoresis on a $3 \%$ agarose gel, stained with ethidium bromide and visualized under UV illumination.

$R T-q P C R$. RT-qPCR was performed using iQ SYBR-Green Supermix (Bio-Rad Laboratories, Inc.). PCR reactions were performed in a total volume of $15 \mu \mathrm{l}$, containing cDNA prepared from $0.2 \mu \mathrm{g}$ total RNA, $0.4 \mu \mathrm{M}$ each gene-specific primer, $7.5 \mu \mathrm{l}$ iQ SYBR-Green Supermix (which contained dATP, dCTP, dGTP and dTTP, each at concentrations of $400 \mu \mathrm{M}$ ) and $50 \mathrm{U} / \mathrm{ml}$ iTag DNA polymerase. The following thermocycling conditions were used: Initial denaturation at $95^{\circ} \mathrm{C}$ for $3 \mathrm{~min}$, followed by 40 cycles of denaturation at $95^{\circ} \mathrm{C}$ for $15 \mathrm{sec}$, annealing at $55^{\circ} \mathrm{C}$ or $60^{\circ} \mathrm{C}$ for $15 \mathrm{sec}$ for SPARC or $\beta$-actin, respectively, and primer extension at $72^{\circ} \mathrm{C}$ for $30 \mathrm{sec}$, followed by a final extension at $72^{\circ} \mathrm{C}$ for $10 \mathrm{~min}$. To distinguish specific from non-specific products 
Table I. Polymerase chain reaction primers and conditions.

Gene $\quad$ Primer $\quad \begin{gathered}\text { Annealing } \\ \text { temperature, }{ }^{\circ} \mathrm{C}\end{gathered} \begin{gathered}\text { Product size, } \\ \text { base pairs }\end{gathered}$

Secreted protein, acidic and cysteine-rich

Sense primer

Anti-sense primer

$\beta$-actin

Sense Primer

Anti-sense primer

\author{
5'-GCTGGATGAGAACAACAC-3' \\ 5'-AAGAAGTGGCAGGAAGAG-3'
}

5'- AGTTGCGTTACACCCTTTCTTGAC-3'

5'- GCTCGCTCCAACCGACTGC-3'
55.0

60.0

171 and primer dimers, melting curve analyses were performed. To evaluate specific mRNA expression in the samples, a standard curve was created for each run, based on three points from human control cDNA (Clontech Laboratories, Inc., CA, USA). The concentrations of each sample were calculated by relating their crossing point to the standard curve. The number of experimental repeats was three times, and the method used for quantitation was relative quantities (19) (iQ5 software version 2.0; Bio-Rad Laboratories, Inc.). $\beta$-actin was used as an internal loading control. PCR primer sequences for amplifying SPARC and $\beta$-actin are presented in Table I.

Immunohistochemistry. Immunohistochemical studies were performed using formalin-fixed, paraffin-embedded tissue specimens obtained from patients with stage II/III gastric cancer. The tissues were fixed with $10 \%$ formalin at room temperature for $48 \mathrm{~h}$. The thickness of the sections was $4 \mu \mathrm{m}$. Tissue sections were deparaffinized with xylene and descending alcohol series $(100 \%$ ethanol twice, $95 \%$ ethanol once and finally $70 \%$ ethanol once) and soaked in $10 \mathrm{mM}$ sodium citrate buffer $\left(\mathrm{pH} \mathrm{9.0)}\right.$ at $121^{\circ} \mathrm{C}$ for $15 \mathrm{~min}$ for antigen retrieval. Sections were subsequently incubated at $4^{\circ} \mathrm{C}$ for $20 \mathrm{~h}$ to allow antigen-antibody binding. Primary polyclonal antibodies against SPARC (dilution, 1:50; cat. no. sc-25574; Santa Cruz Biotechnology, Inc., Dallas, TX, USA). A peroxidase-labeled polymer (undiluted; EnVision ${ }^{+}$anti-rabbit immunoglobulin/goat polyclonal antibody; cat. no. K4002; Dako; Agilent Technologies, Inc., Santa Clara, CA, USA) was used to detect signals of the antigen-antibody reaction at room temperature for $30 \mathrm{~min}$, and the internal control using a rabbit immunoglobulin antibody (dilution, 1:5,000; cat. no. X0903; Dako; Agilent Technologies, Inc.) Blocking reagent was 3\% hydrogen peroxide at room temperature for $5 \mathrm{~min}$. All sections were counterstained at room temperature for $50 \mathrm{sec}$ with hematoxylin. Immunohistochemistry was viewed using a light microscope at a magnification of $\mathrm{x} 200$.

Statistical analysis. SPARC gene expression levels in gastric cancer tissues were compared with those in adjacent normal mucosa using the Wilcoxon signed-rank test. A univariate Cox proportional hazards model was used to evaluate the degree of association between overall survival rates and $S P A R C$ gene expression levels and other potential prognostic factors, including age, sex, histological type, tumor size, depth of invasion, lymph-node metastasis, number of lymph-node metastases, lymphatic invasion, venous invasion and TNM stage. Cut-off values of SPARC gene expression levels were evaluated using a multivariate Cox proportional hazards model comprising prognostic factors that were significantly associated with overall survival rates in univariate analysis. The optimal cut-off value was selected by the minimum P-value method, and the internal validity of the cut-off value was evaluated using a 2-fold cross-validation approach (20). The association between gene expression levels and potential prognostic factors was evaluated using the $\chi^{2}$ test. The postoperative survival rate was evaluated using the Kaplan-Meier method, and differences in survival rates were assessed with the log-rank test. $\mathrm{P}<0.05$ was considered to indicate a statistically significant difference. All statistical analyses were conducted using SPSS software, version 22 for Windows (IBM Corp., Armonk, NY, USA), and SAS, version 9.3 (SAS Institute, Inc., Cary, NC, USA).

\section{Results}

Immunohistochemistry of SPARC expression. SPARC expression was evaluated in gastric cancer tissues by immunohistochemical analysis. Although SPARC immunopositive staining was observed in both stromal and cancer cells, expression was higher in the former (Fig. 3).

SPARC mRNA expression in gastric cancer cell lines and patient tissue samples. Expression of SPARC mRNA in human gastric cancer cell lines and patient tissue samples was analyzed by RT-PCR. SPARC mRNA was expressed in human gastric cancer MKN1, MKN7, MKN74 and NUGC-3 cell lines (Fig. 4A), but its expression varied from low to high depending on the cell line. MKN1 and MKN7 were highly expressed, but MKN74 and NUGC-3 had a low expression. RT-PCR analysis of $S P A R C$ mRNA expression in gastric cancer tissue samples and adjacent normal mucosa $(\mathrm{n}=7)$ revealed that $S P A R C$ mRNA was expressed in both tissue types, but that expression was higher in gastric cancer tissues than in adjacent normal mucosa (Fig. 4B).

SPARC mRNA levels are higher in gastric cancer tissues than in adjacent normal mucosa. SPARC mRNA expression in patient tissue samples by was confirmed by RT-qPCR. SPARC mRNA levels were significantly higher in cancer tissues than in normal adjacent mucosa $(\mathrm{P}=0.0012$; Fig. 5).

Univariate and multivariate analyses of potential prognostic variables, SPARC gene expression and postoperative patient outcomes. SPARC mRNA expression levels $(\mathrm{P}=0.0021)$ and 
A
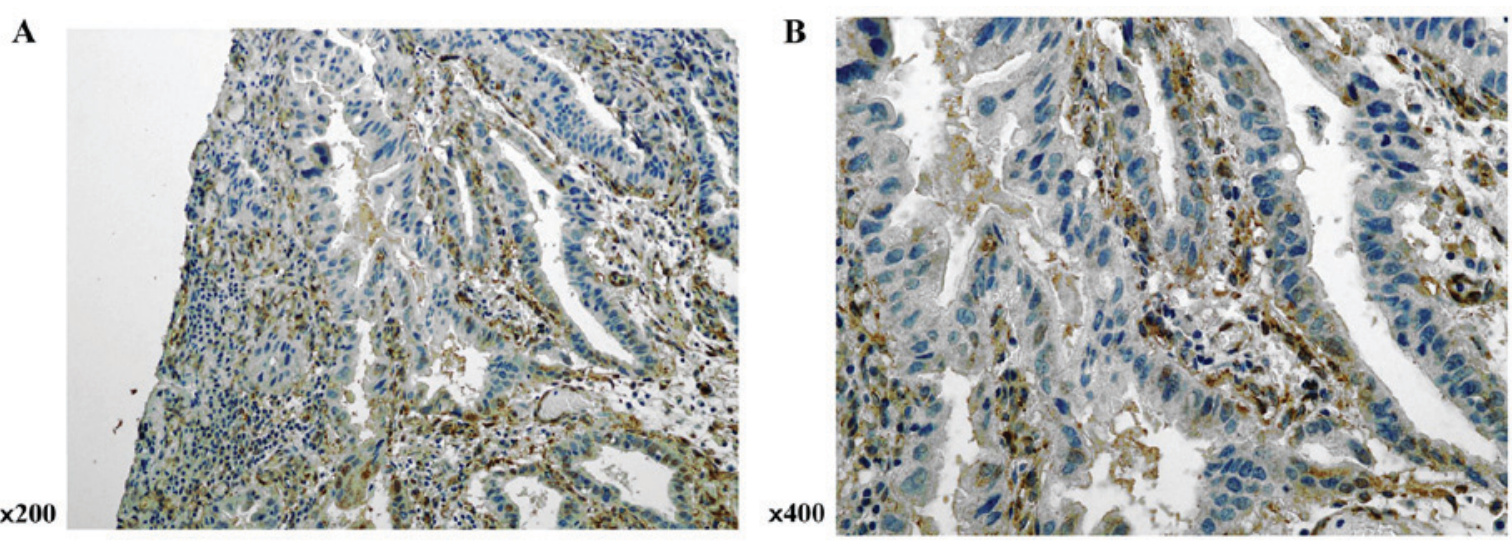

Figure 3. Expression of SPARC was evaluated by immunohistochemical analysis of resected gastric cancer specimens. Positive staining for SPARC was observed in stromal cells and cancer cells, but was markedly more intense in stromal cells than in cancer cells. (A) x200; and (B) x400. SPARC, secreted protein, acidic and cysteine-rich.

A MKN1 MKN7 MKN45 MKN74 NUGC3 NUGC4 KATOIII p n
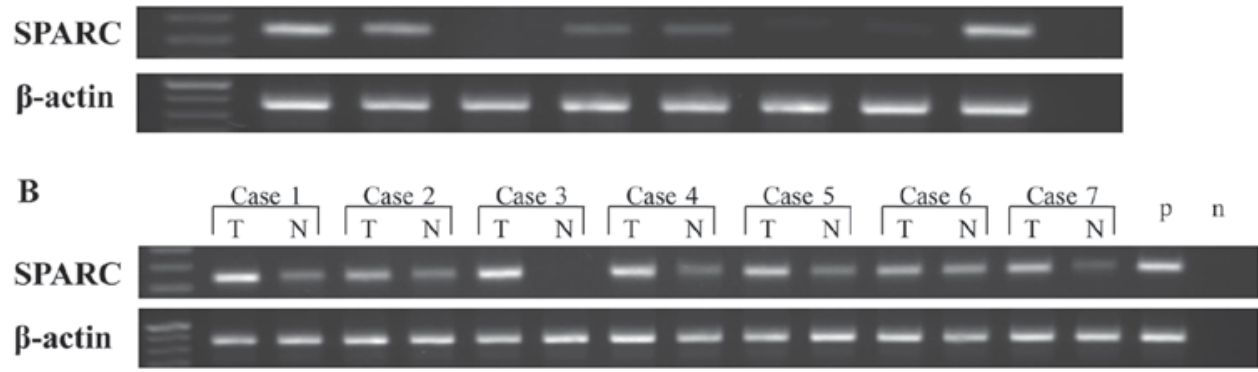

Figure 4. SPARC and $\beta$-actin mRNA expression in (A) 7 gastric cancer cell lines and (B) clinical samples, as determined by reverse-transcription polymerase chain reaction. The product size of SPARC and $\beta$-actin was 126 and 171 base pairs, respectively. SPARC, secreted protein, acidic and cysteine-rich; p, positive control; $\mathrm{n}$, negative control; $\mathrm{T}$, tumor; $\mathrm{N}$, adjacent normal mucosa.

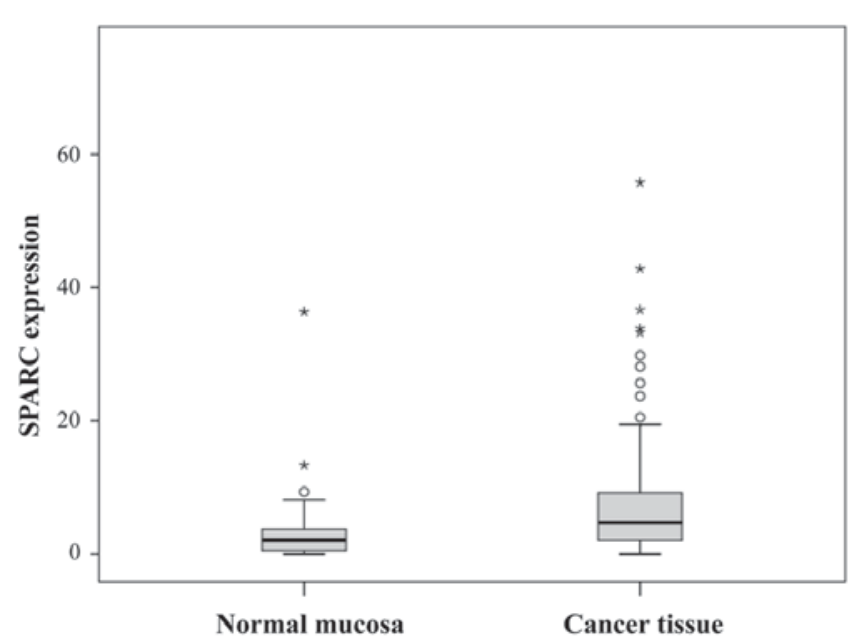

Figure 5. Comparison of SPARC expression levels between gastric cancer tissues and adjacent normal mucosa $(\mathrm{P}=0.0012$, as determined using the Wilcoxon's signed rank test). Box indicates the interquartile range (25-75\%), the horizontal line indicates the mean and the bars indicates the first and ninth decile. SPARC, secreted protein, acidic and cysteine-rich.

TNM stage $(\mathrm{P}=0.041)$ were associated with patient survival in univariate analysis using a Cox proportional hazards model. Other variables, including age, sex, tumor size, histological type, $\mathrm{T}$ factor, number of lymph-node metastases, lymphatic invasion and venous invasion were not statistically significant predictors of patient survival (Table II). SPARC expression levels were then categorized as low or high in multivariate analysis, using the prognostic factors identified in univariate analysis, with a Cox proportional hazards model (cut-off point, 7.101). A 2-fold cross-validation approach confirmed that high $S P A R C$ gene expression was a significant predictor of poor survival in patients with stage II/III gastric cancer (HR, 5.347; 95\% CI 2.493-11.468; P<0.0001; Table III).

Association between SPARC gene expression and potential prognostic variables. Patient tissue samples were divided into two groups [low expression group $(n=73)$ and high expression group ( $\mathrm{n}=61)$ ] according to their SPARC mRNA expression levels (cut-point, 7.101). SPARC gene expression levels were not associated with any of the potential prognostic variables analyzed in the present study (Table IV).

Survival curves of patients, ranked by SPARC mRNA expression levels. The overall survival rates of patients were plotted relative to the measured SPARC mRNA expression levels using the Kaplan-Meier method. The median follow-up was 1,107 days. In the study group ( $n=134$ patients), the overall survival rate was lower in patients with high SPARC mRNA expression than in those with low SPARC mRNA expression $(\mathrm{P}=0.000006$; Fig. 6). Among patients with stage II $(\mathrm{n}=40)$ and 
Table II. Univariate analysis of potential prognostic variables for overall survival.

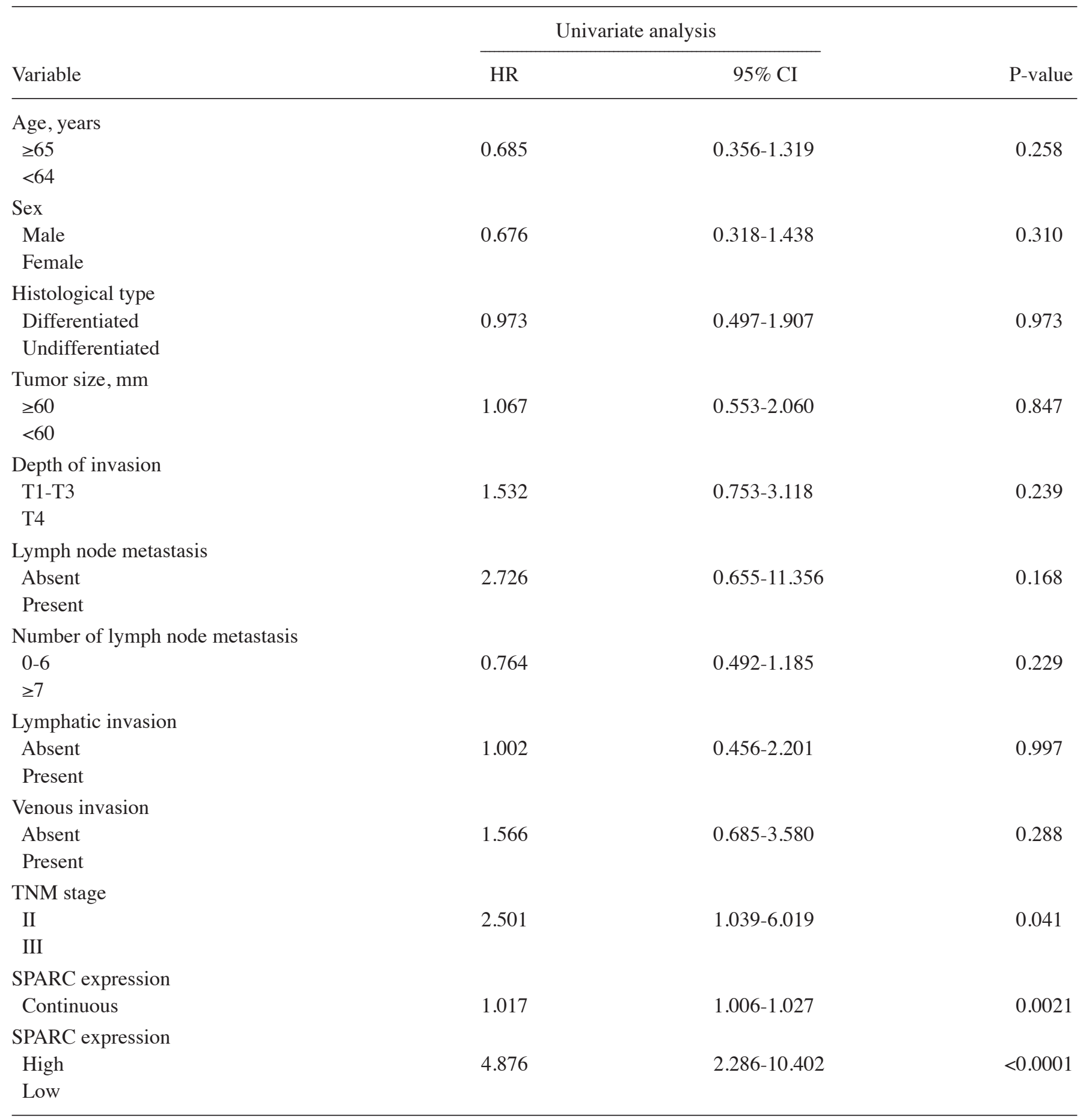

HR, hazards ratio; CI, confidence interval; T, tumor stage; TNM, Tumor-Node-Metastasis; SPARC, secreted protein, acidic and cysteine-rich.

stage III $(\mathrm{n}=94)$ cancer, the overall survival rate was lower in patients with high SPARC mRNA expression than in those with low SPARC mRNA expression $(\mathrm{P}=0.036$ and $\mathrm{P}=0.0000017$, respectively; Figs. 7 and 8, respectively). However, no statistically significant differences in the survival rates of patients in the reference group who were diagnosed with stage II/III gastric cancer and had undergone surgical resection, but had not received adjuvant chemotherapy with $\mathrm{S}-1 \quad(\mathrm{n}=103)$, were observed between the low or high SPARC expression groups ( $\mathrm{P}=0.732$; Fig. 9).

\section{Discussion}

The results of the present study demonstrated that SPARC mRNA expression levels were higher in gastric cancer tissues than in adjacent normal mucosa, which is in line with the results of previous studies $(17,21)$.

In addition, through univariate and multivariate analyses of potential prognostic factors using Cox proportional hazards models, high SPARC expression was revealed to be a significant predictor of poor survival in patients with stage II/III 
Table III. Multivariate analysis of potential prognostic variables for overall survival.

\begin{tabular}{lccc}
\hline & \multicolumn{2}{c}{ Multivariate analysis } & \\
\cline { 2 - 3 } Variable & HR & $95 \% \mathrm{CI}$ & P-value \\
\hline TNM stage & & & \\
II & 1.229 & $0.378-3.995$ & 0.732 \\
III & & & \\
SPARC expression & & & \\
$\quad$ High & 5.347 & $2.493-11.468$ & $<0.0001$ \\
Low & & & \\
\hline
\end{tabular}

HR, hazards ratio; CI, confidence interval; TNM, Tumor-NodeMetastasis; SPARC, secreted protein, acidic and cysteine-rich.

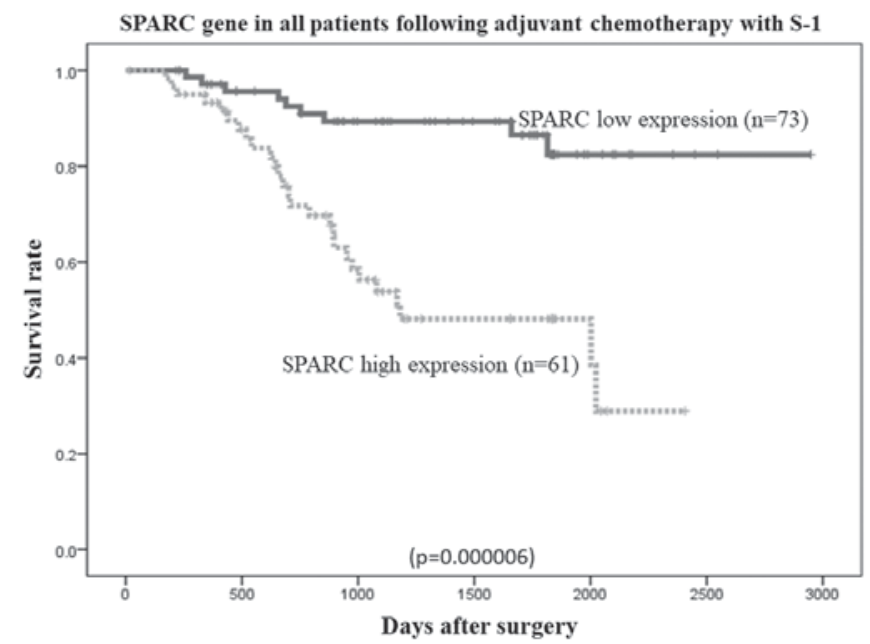

Figure 6. Comparison of overall survival rates between low and high SPARC expression levels in patients who had following adjuvant S-1 chemotherapy $(\mathrm{P}=0.000006$, as determined using the log-rank test). SPARC, secreted protein, acidic and cysteine-rich.

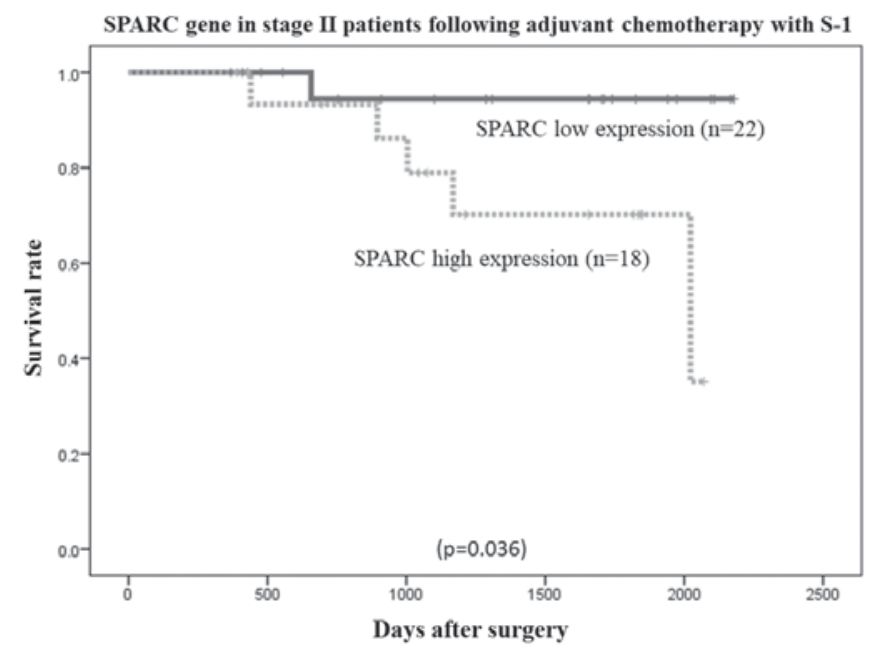

Figure 7. Comparison of overall survival rates between high and low SPARC expression levels in patients with stage II gastric cancer who had following adjuvant $\mathrm{S}-1$ chemotherapy ( $\mathrm{P}=0.036$, as determined using the log-rank test) SPARC, secreted protein, acidic and cysteine-rich.

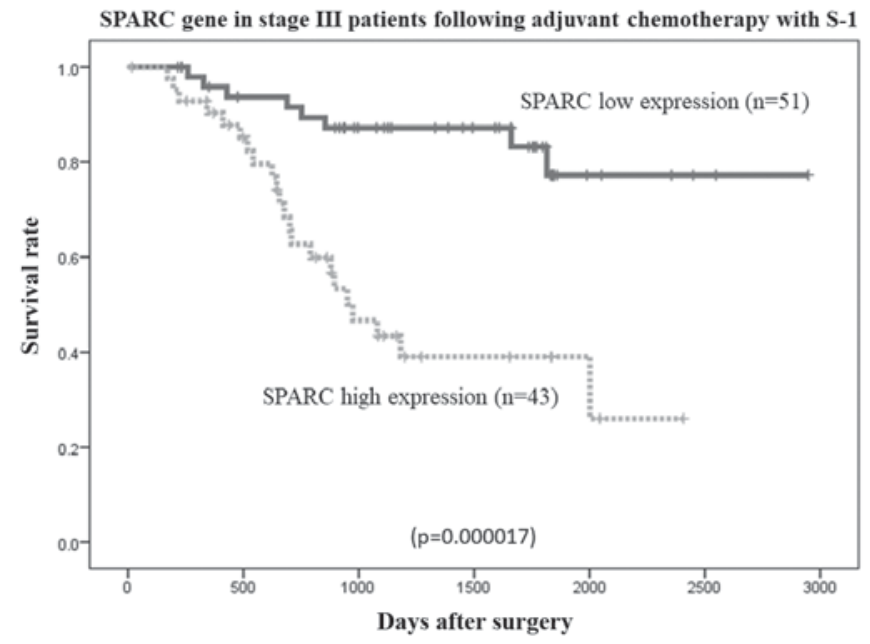

Figure 8. Comparison of overall survival rates between high and low SPARC expression levels in patients with stage III gastric cancer who had following adjuvant $\mathrm{S}-1$ chemotherapy $(\mathrm{P}=0.000017$, as determined using the log-rank test). SPARC, secreted protein, acidic and cysteine-rich.

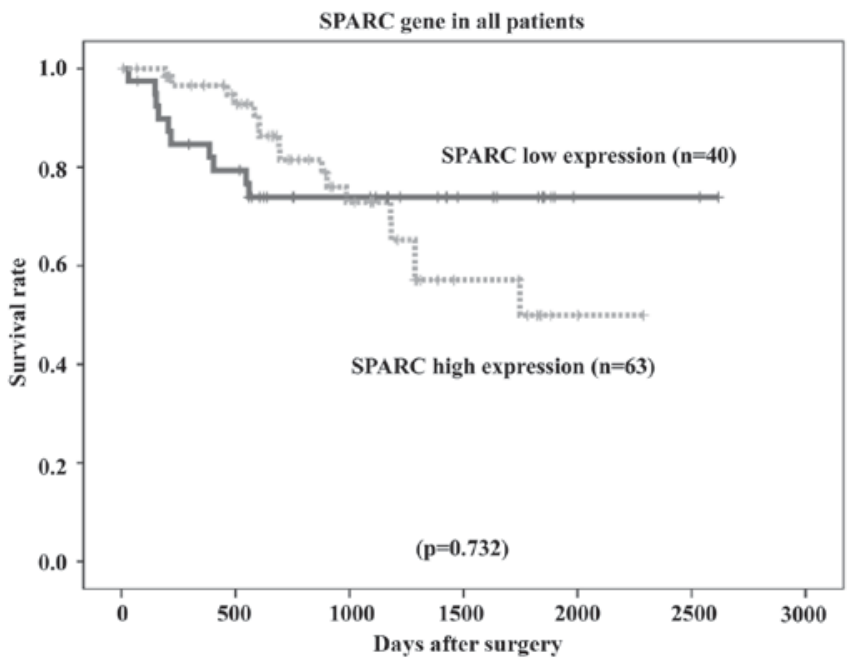

Figure 9. Comparison of overall survival rates between high and low SPARC expression levels in the patients who had not received adjuvant S-1 chemotherapy $(\mathrm{P}=0.732$, as determined using the log-rank test). SPARC, secreted protein, acidic and cysteine-rich.

gastric cancer, who had undergone curative surgical resection and adjuvant chemotherapy with $\mathrm{S}-1$. However, no statistical differences in the overall survival rate of patients with stage II/III cancer who had undergone curative resection but had not received adjuvant chemotherapy with S-1 were observed between patients with low or high SPARC expression. The results of the present study are consistent with those of previous studies reporting an association between high SPARC gene expression and poor patient outcomes. Koukourakis et al (22) reported that high SPARC expression was associated with poor outcomes in patients with stage I/II non-small cell lung cancer who had undergone surgical resection. Infante et al (23) reported that patients whose pancreatic cancer stroma expressed $S P A R C$ exhibited a significantly poorer outcome than patients whose tumor stroma did not express SPARC. Zhao et al (16) also reported that high SPARC expression was significantly associated with poorer 5-year 
Table IV. Association between SPARC gene expression and potential prognostic variables.

\begin{tabular}{|c|c|c|c|}
\hline \multirow[b]{2}{*}{ Variable } & \multicolumn{2}{|c|}{ SPARC expression } & \multirow[b]{2}{*}{ P-value } \\
\hline & $\begin{array}{c}\text { Low } \\
(n=73)\end{array}$ & $\begin{array}{l}\text { High } \\
(n=61)\end{array}$ & \\
\hline \multicolumn{4}{|l|}{ Age, years } \\
\hline$\geq 65$ & 43 & 35 & \multirow[t]{2}{*}{0.499} \\
\hline$<64$ & 30 & 26 & \\
\hline \multicolumn{4}{|l|}{ Sex } \\
\hline Male & 48 & 44 & \multirow[t]{2}{*}{0.273} \\
\hline Female & 25 & 17 & \\
\hline \multicolumn{4}{|l|}{ Histological type } \\
\hline Differentiated & 28 & 25 & \multirow[t]{2}{*}{0.447} \\
\hline Undifferentiated & 45 & 36 & \\
\hline \multicolumn{4}{|l|}{ Tumor size } \\
\hline$\geq 60 \mathrm{~mm}$ & 44 & 30 & \multirow[t]{2}{*}{0.133} \\
\hline$<60 \mathrm{~mm}$ & 29 & 31 & \\
\hline \multicolumn{4}{|l|}{ Depth of invasion } \\
\hline $\mathrm{T} 1-\mathrm{T} 3$ & 29 & 24 & \multirow[t]{2}{*}{0.553} \\
\hline $\mathrm{T} 4$ & 44 & 37 & \\
\hline \multicolumn{4}{|c|}{ Lymph node metastasis } \\
\hline Absent & 8 & 8 & \multirow[t]{2}{*}{0.451} \\
\hline Present & 65 & 53 & \\
\hline \multicolumn{4}{|c|}{ Number of lymph node metastasis } \\
\hline $0-6$ & 46 & 35 & \multirow[t]{2}{*}{0.313} \\
\hline$\geq 7$ & 27 & 26 & \\
\hline \multicolumn{4}{|l|}{ Lymphatic invasion } \\
\hline Absent & 17 & 13 & \multirow[t]{2}{*}{0.475} \\
\hline Present & 56 & 48 & \\
\hline \multicolumn{4}{|l|}{ Venous invasion } \\
\hline Absent & 22 & 11 & \multirow[t]{2}{*}{0.077} \\
\hline Present & 51 & 50 & \\
\hline \multicolumn{4}{|l|}{ TNM stage } \\
\hline II & 22 & 18 & \multirow[t]{2}{*}{0.545} \\
\hline III & 51 & 43 & \\
\hline
\end{tabular}

SPARC, secreted protein, acidic and cysteine-rich; T, tumor stage; TNM, Tumor-Node-Metastasis.

survival rates for patients with all stages of gastric cancer. Furthermore, Jeung et al (24) reported that high SPARC expression was associated with early progressive disease (PD) and poor survival in patients with unresectable gastric cancer who had received combinatorial S-1 plus docetaxel chemotherapy.

Analysis of the potential association between SPARC gene expression and various clinicopathological features revealed no significant associations in patients with stage II/III gastric cancer who had undergone surgical resection followed by adjuvant chemotherapy with $\mathrm{S}-1$. However, previous studies have reported that high SPARC gene expression is associated with the depth of tumor invasion of stage I-IV gastric cancer (25), lymph node metastasis in esophageal cancer (26), tumor size, degree of differentiation, depth of invasion, vascular invasion, lymph-node metastases, distant metastases and TNM stage in gastric cancer $(16,17)$.

The molecular mechanisms underlying the association between SPARC gene expression and the outcomes of patients with gastric cancer remain to be fully elucidated. McClung et al (27) reported that SPARC upregulated MT1-MMP expression and MMP2 activity in SPARC-transfected clones of glioma cells. These MMPs induce degradation of the extracellular matrix and promote cancer cell invasion and metastasis, leading to poorer outcomes (28). In vitro, SPARC inhibits apoptosis by interacting with integrin $\beta 1$ heterodimers that enhance integrin-linked kinase activation (29). Chemoresistance due to anti-apoptotic activity of SPARC was suggested to be associated with poor treatment prognosis in patients with 
unresectable gastric cancer. Further studies are required to clarify whether high SPARC levels may result in nonspecific chemoresistance.

Using coimmunoprecipitation experiments, Huynh et al (30) demonstrated an association between SPARC expression and tubulin in Xenopus embryonic cell lysates, indicating a role for SPARC in mitosis. Recently, SPARC has been suggested to participate in the tumor response to taxanes, which stabilize microtubules, thereby preventing tumor cell division. In previous studies on patients with breast cancer, SPARC was selected as a candidate biomarker of the response to docetaxel (24) and was suggested as a useful biomarker of the effectiveness of nab-paclitaxel therapy $(31,32)$.

The standard treatment for stage II/III gastric cancer is curative resection and follow-up chemotherapy with fluoropyrimidine anticancer agents, including S-1. According to Japanese gastric cancer treatment guidelines (2014), second-line chemotherapies, including paclitaxel and ramucirumab, are recommended for the treatment of patients with recurring gastric cancer (33). Although high SPARC expression increases the probability of recurrence following first-line treatment, it may explain the high therapeutic effect of paclitaxel for the aforementioned reasons. Therefore, SPARC may represent an important biomarker in designing a treatment strategy for patients with recurring stage II/III gastric cancer.

High SPARC gene expression is a significant prognostic indicator of the outcomes of patients with stage II/III gastric cancer following curative resection and adjuvant chemotherapy with S-1.

\section{Acknowledgements}

Not applicable.

\section{Funding}

No funding was received.

\section{Availability of data and materials}

All data generated or analyzed during this study are included in this published article.

\section{Authors' contributions}

YS and TO were responsible for the conception and design of the study. TO and KY were responsible for the development of methodology. TA, HC, MS, TY and YR performed the collection of specimens, and YS, TO, KS, TI and MM performed analysis and interpretation of the data.

\section{Ethics approval and consent to participate}

Study protocols were approved by the Ethics Committees of Yokohama City University Medical Center, Yokohama City University (approval number: 18-7A-4) and Kanagawa Cancer Center (approval number: epidemiological study-29) prior to the initiation of the present study. Written informed consent was obtained from each patient.

\section{Consent for publication}

Written informed consent was obtained from each patient.

\section{Competing interests}

The authors declare that they have no competing interests.

\section{References}

1. Torre LA, Bray F, Siegel RL, Ferlay J, Lortet-Tieulent J and Jemal A: Global cancer statistics, 2012. CA Cancer J Clin 65: 87-108, 2015.

2. Sakuramoto S, Sasako M, Yamaguchi T, Kinoshita T, Fujii M, Nashimoto A, Furukawa H, Nakajima T, Ohashi Y, Imamura H, et al: Adjuvant chemotherapy for gastric cancer with S-1, an oral fluoropyrimidine. N Engl J Med 357: 1810-1820, 2007.

3. Sasako M, Sakuramoto S, Katai H, Kinoshita T, Furukawa H, Yamaguchi T, Nashimoto A, Fujii M, Nakajima T and Ohashi Y: Five-year outcomes of a randomized phase III trial comparing adjuvant chemotherapy with S-1 versus surgery alone in stage II or III gastric cancer. J Clin Oncol 29: 4387-4393, 2011.

4. Termine JD, Kleinman HK, Whitson SW, Conn KM, McGarvey ML and Martin GR: Osteonectin, a bone-specific protein linking mineral to collagen. Cell 26: 99-105, 1981.

5. Mann K, Deutzmann R, Paulsson M and Timpl R: Solubilization of protein BM-40 from a basement membrane tumor with chelating agents and evidence for its identity with osteonectin and SPARC. FEBS Lett 218: 167-172, 1987.

6. Nagaraju GP and Sharma D: Anti-cancer role of SPARC, an inhibitor of adipogenesis. Cancer Treat Rev 37: 559-566, 2011.

7. Guweidhi A, Kleeff J, Adwan H, Giese NA, Wente MN, Giese T, Büchler MW, Berger MR and Friess H: Osteonectin influences growth and invasion of pancreatic cancer cells. Ann Surg 242: 224-234, 2005

8. Bornstein P and Sage EH: Matricellular proteins: Extracellular modulators of cell function. Curr Opin Cell Biol 14: 608-616, 2002.

9. Podhajcer OL, Benedetti LG, Girotti MR, Prada F, Salvatierra E and Llera AS: The role of the matricellular protein SPARC in the dynamic interaction between the tumor and the host. Cancer Metastasis Rev 27: 691-705, 2008.

10. Hsiao YH, Lien HC, Hwa HL, Kuo WH, Chang KJ and Hsieh FJ: SPARC (osteonectin) in breast tumors of different histologic types and its role in the outcome of invasive ductal carcinoma. Breast J 16: 305-308, 2010.

11. Thomas R, True LD, Bassuk JA, Lange PH and Vessella RL: Differential expression of osteonectin/SPARC during human prostate cancer progression. Clin Cancer Res 6: 1140-1149, 2000.

12. Chan SK, Griffith OL, Tai IT and Jones SJ: Meta-analysis of colorectal cancer gene expression profiling studies identifies consistently reported candidate biomarkers. Cancer Epidemiol Biomarkers Prev 17: 543-552, 2008.

13. Franke K, Carl-McGrath S, Röhl FW, Lendeckel U, Ebert MP, Tänzer M, Pross M and Röcken C: Differential expression of SPARC in intestinal-type gastric cancer correlates with tumor progression and nodal spread. Transl Oncol 2: 310-320, 2009.

14. Ledda F, Bravo AI, Adris S, Bover L, Mordoh J and Podhajcer OL: The expression of the secreted protein acidic and rich in cysteine (SPARC) is associated with the neoplastic progression of human melanoma. J Invest Dermatol 108: 210-214, 1997.

15. Rempel SA, Golembieski WA, Ge S, Lemke N, Elisevich K, Mikkelsen T and Gutiérrez JA: SPARC: A signal of astrocytic neoplastic transformation and reactive response in human primary and xenograft gliomas. J Neuropathol Exp Neurol 57: 1112-1121, 1998.

16. Zhao ZS, Wang YY, Chu YQ, Ye ZY and Tao HQ: SPARC is associated with gastric cancer progression and poor survival of patients. Clin Cancer Res 16: 260-268, 2010.

17. Wang L, Yang M, Shan L, Qi L, Chai C, Zhou Q, Yao K, Wu H and Sun W: The role of SPARC protein expression in the progress of gastric cancer. Pathol Oncol Res 18: 697-702, 2012.

18. Sobin LH, Gospodarowicz MK and Wittekind C; UICC International Union Against Cancer: TNM Classification of Malignant Tumours. 7th edition. Wiley-Blackwell, Chichester, West Sussex, UK, 2009. 
19. Livak KJ and Schmittgen TD: Analysis of relative gene expression data using real-time quantitative PCR and the 2(-Delta Delta C(T)) method. Methods 25: 402-408, 2001.

20. Mazumdar M, Smith A and Bacik J: Methods for categorizing a prognostic variable in a multivariable setting. Stat Med 22: 559-571, 2003.

21. Maeng HY, Song SB, Choi DK, Kim KE, Jeong HY, Sakaki Y and Furihata C: Osteonectin-expressing cells in human stomach cancer and their possible clinical significance. Cancer Lett 184 117-121, 2002.

22. Koukourakis MI, Giatromanolaki A, Brekken RA, Sivridis E, Gatter KC, Harris AL and Sage EH: Enhanced expression of SPARC/osteonectin in the tumor-associated stroma of non-small cell lung cancer is correlated with markers of hypoxia/acidity and with poor prognosis of patients. Cancer Res 63: 5376-5380, 2003

23. Infante JR, Matsubayashi H, Sato N, Tonascia J,Klein AP, Riall TA Yeo C, Iacobuzio-Donahue C and Goggins M: Peritumoral fibroblast SPARC expression and patient outcome with resectable pancreatic adenocarcinoma. J Clin Oncol 25: 319-325, 2007.

24. Jeung HC, Rha SY, Im CK, Shin SJ, Ahn JB, Yang WI, Roh JK, Noh SH and Chung HC: A randomized phase 2 study of docetaxel and $\mathrm{S}-1$ versus docetaxel and cisplatin in advanced gastric cancer with an evaluation of SPARC expression for personalized therapy. Cancer 117: 2050-2057, 2011.

25. Sato T, Oshima T, Yamamoto N, Yamada T, Hasegawa $S$, Yukawa N, Numata K, Kunisaki C, Tanaka K, Shiozawa M, et al: Clinical significance of SPARC gene expression in patients with gastric cancer. J Surg Oncol 108: 364-368, 2013.

26. Yamashita K, Upadhay S, Mimori K, Inoue H and Mori M Clinical significance of secreted protein acidic and rich in cystein in esophageal carcinoma and its relation to carcinoma progression. Cancer 97: 2412-2419, 2003.
27. McClung HM, Thomas SL, Osenkowski P, Toth M, Menon P, Raz A, Fridman R and Rempel SA: SPARC upregulates MT1-MMP expression, MMP-2 activation, and the secretion and cleavage of galectin-3 in U87MG glioma cells. Neurosci Lett 419: 172-177, 2007.

28. Egeblad M and Werb Z: New functions for the matrix metalloproteinases in cancer progression. Nat Rev Cancer 2: 161-174, 2002.

29. Weaver MS, Workman G and Sage EH: The copper binding domain of SPARC mediates cell survival in vitro via interaction with integrin betal and activation of integrin-linked kinase. J Biol Chem 283: 22826-22837, 2008.

30. Huynh MH, Sodek K, Lee H and Ringuette M: Interaction between SPARC and tubulin in Xenopus. Cell Tissue Res 317: 313-317, 2004.

31. Desai NP, Trieu V, Hwang LY, Wu R, Soon-Shiong P and Gradishar WJ: Improved effectiveness of nanoparticle albuminbound (nab) paclitaxel versus polysorbate-based docetaxel in multiple xenografts as a function of HER2 and SPARC status. Anticancer Drugs 19: 899-909, 2008.

32. Gradishar WJ: Albumin-bound paclitaxel: A next-generation taxane. Expert Opin Pharmacother 7: 1041-1053, 2006.

33. Wilke H, Muro K, Van Cutsem E, Oh SC, Bodoky G, Shimada Y, Hironaka S, Sugimoto N, Lipatov O, Kim TY, et al: Ramucirumab plus paclitaxel versus placebo plus paclitaxel in patients with previously treated advanced gastric or gastro-oesophageal junction adenocarcinoma (RAINBOW): A double-blind, randomised phase 3 trial. Lancet Oncol 15: 1224-1235, 2014. 